\title{
Visceral leishmaniasis due to Leishmania infantum with renal involvement in HIV-infected patients
}

\author{
Matteo Vassallo ${ }^{1 *+}$, Olivier Moranne $e^{2,3,4+}$, Damien Ambrosetti ${ }^{5}$, Pierre-Yves Jeandel ${ }^{6}$, Christelle Pomares ${ }^{7}$, \\ Elisabeth Cassuto ${ }^{2}$, Annick Boscagli ${ }^{1}$, Guillaume Giraud ${ }^{1}$, Nathalie Montagne ${ }^{1}$, Chiara Dentone ${ }^{8}$, Ilaria Demacina ${ }^{8}$, \\ Barbara Villaggio ${ }^{9}$, Giovanni Secondo ${ }^{8}$, Giuseppe Ferrea ${ }^{8}$, Corinne Passeron $^{10}$, Laurence Saudes ${ }^{1}$, Regis Kaphan ${ }^{1}$, \\ Pierre Marty ${ }^{7}$ and Eric Rosenthal ${ }^{6}$
}

\begin{abstract}
Background: We describe histological, clinical findings and outcomes of renal involvement during Leishmania infantum infection in four HIV-infected patients in South France and North Italy hospital settings.

Cases presentation: Four HIV-infected Caucasian patients (age 24-49) performed renal biopsy during episodes of visceral leishmaniasis. They presented severe immunosuppression, frequent relapses of visceral leishmaniasis during a follow-up period of several years and partial or complete recovery of renal function after anti-parasitic treatment. Main clinical presentations were nephrotic or nephritic syndrome and/or acute renal failure secondary to membranoproliferative type III glomerulonephritis or acute interstitial nephritis. Clinical outcome was poor, probably as a consequence of insufficient immuno-virological control of the HIV infection.

Conclusions: Our findings suggest that the main histological findings in case of renal involvement due to Leishmania infantum infection in HIV-infected patients are type III MPGN and acute interstitial nephritis, with a histological specificity similar to that observed in canine leishmaniasis. Poor immune status in HIV-infected patients, altering the capacity for parasite clearance, and prolonged course of chronic active VL in this population may lead to the development of specific renal lesions.
\end{abstract}

\section{Background}

Leishmaniasis due to Leishmania infantum is a vectorborne disease which is endemic in Southern Europe [1-5]. In humans, Leishmania infection gives rise to a range of presentations (mainly visceral, cutaneous and mucosal) depending on the species involved and the effectiveness of the patient's immune response to the parasite $[2,6,7]$. Visceral leishmaniasis $(\mathrm{VL})$ is present in 61 countries across 4 continents where 200 million people are exposed. Approximately 0.2 to 0.4 million cases of VL and 0.7 to 1.2 million cases of cutaneous leishmaniasis occur each year, with 5 countries (India, Nepal, Bangladesh, Sudan, Brazil) accounting for $90 \%$ of these, whereas the condition remains sporadic in Southern Europe [1-4]. In immunosuppressed individuals, including HIV-infected patients, the clinical presentation of VL can

\footnotetext{
* Correspondence: m.vassallo@ch-cannes.fr

${ }^{\dagger}$ Equal contributors

'Department of Internal Medicine, Cannes General Hospital, Cannes, France

Full list of author information is available at the end of the article
}

be atypical [8], easily misdiagnosed or mistaken as a flareup of the underlying disease. Before the introduction of combination antiretroviral therapy (cART), the incidence of VL was higher in HIV-infected patients than in immunocompetent subjects, with higher rates of relapse and mortality [2]. In the cART era, the incidence of VL in the HIV-infected population has dramatically decreased [9-13]. Moreover, with the longer life expectancy of HIV-infected individuals, new clinical features of VL have been reported, such as active chronic VL, characterized by relapses over a period of several years and continuous circulation of the parasite in the bloodstream [14].

Renal involvement in HIV-infected patients with VL is uncommon and few cases have been reported [15-19]. Patients displayed various patterns of clinical and histological presentation: isolated proteinuria or hematuria, nephrotic syndrome (proteinuria $>2.5 \mathrm{~g} / \mathrm{day}$, hypoalbuminemia and generalized œedema), nephritic syndrome (glomerular proteinuria \& hematuria, reduced glomerular filtration rate with varying degrees of azotemia, 
oliguria and hypertension) secondary to membranoproliferative glomerulonephritis (MPGN) or amyloidosis, and acute kidney injury (AKI) secondary to interstitial nephritis [15-22].

We present a series of four cases of VL due to Leishmania infantum with renal involvement in HIV-infected patients, including histological findings and clinical outcome. Patients were hospitalized between 1996 and 2012 in Infectious Diseases Hospital departments in the Alpes-Maritimes, France and in Liguria, Italy, where Leishmania infantum infection is endemic.

\section{Cases presentation}

\section{Case report $\mathrm{n}^{\circ} 1$}

A 40-year-old HIV-infected male patient, born and residing in the Nice area (Alpes-Maritimes, South-Eastern France), was admitted to hospital in June 2011 for persistent diarrhœa and weight loss (5 kgs). He had contracted HIV-infection in 1996, and his previous medical history included VL in 2000, (with clinical relapses in 2005 and 2009 but no renal involvement), high blood pressure, cerebral toxoplasmosis and Kaposi's sarcoma in 2003, and pneumocystis pneumonia in 2006. His antiretroviral regimen included etravirine, darunavir and ritonavir. The latest CD4 cell count was 114 cells $/ \mathrm{mm}^{3}$ (nadir: 46 cells $/ \mathrm{mm}^{3}$ ) and HIV viral load was 162 copies $/ \mathrm{ml}$. Compliance with cART had frequently been sub-optimal. He presented with nephritic syndrome, urine dipstick analysis revealing proteinuria and hematuria, but no leukocyturia. Blood pressure was 150/100 $\mathrm{mmHg}$, with peripheral œdema. All kidney tissue samples were obtained via needle biopsy. Light microscopy examination showed diffuse hyper-cellularity with thickening of the glomerular basement membrane, and immunofluorescence microscopy revealed IgG, IgM, C3 and C1q mesangial and endo-membranous deposits. According to the World Health Organisation (WHO) classification, the histological findings were typical of type III membranoproliferative glomerulonephritis (MPGN).

Diagnosis of VL was based on molecular methods using Leishmania infantum polymerase chain reaction (PCR) (Taqman technology; Light Cycler target: kinetoplast mini-circle DNA) on peripheral blood and other biological samples, i.e. bone marrow, urine and kidney [23]. In this patient, qualitative PCR was positive in both urine and peripheral blood. VL relapse was suspected and liposomal Amphotericine B (l-Ampho-B), $3 \mathrm{mg} / \mathrm{kg}$ daily, initially scheduled for 10 days, was prematurely discontinued due to deteriorating renal function and suspected drug-associated tubulopathy. The patient's condition gradually improved and secondary VL prophylaxis consisting in monthly intravenous pentamidine infusions was initiated. During follow-up, creatinine levels remained stable and viro-immunological parameters improved. The patient was re-admitted in October 2013 for another relapse of VL. Poor cART compliance was suspected. The CD4 T-cell count and plasma HIV-RNA level were 79 cells $/ \mathrm{mm}^{3}$ and 1,500 copies $/ \mathrm{ml}$, respectively. PCR was positive for Leishmania infantum with 992 parasites $/ \mathrm{ml}$ in plasma and 322 parasites $/ 10^{6}$ cells in bone marrow. Treatment with l-Ampho-B was started, adapting dosage to renal function; fever resolved, parasitemia dropped to 312 parasites $/ \mathrm{ml}$ and the estimated glomerular filtration rate (eGFR) remained stable. Antiretroviral treatment was switched from a twice-daily to a once-daily regimen, in order to improve compliance. The patient was discharged and continued secondary VL prophylaxis as an outpatient with L-Ampho-B.

Table 1 summarizes baseline characteristics, renal impairment and clinical outcome for all four patients, while the main histological findings are described in Table 2.

\section{Case report $\mathrm{n}^{\circ} \mathbf{2}$}

A 35-year-old male patient, HIV-infected since 1997, born and residing in the Nice area (Alpes-Maritimes, SouthEastern France), was first admitted to hospital in 1998 with VL. He was treated with l-Ampho-B and symptoms improved. During the following years, the patient had several relapses of VL despite various secondary prophylaxis regimens, including l-ampho-B, pentamidine and miltefosine. In 2004 he was re-admitted with suspected clinical relapse of VL. His CD4 cell count was 20 cells $/ \mathrm{mm}^{3}$ while HIV viral load exceeded 100,000 copies/ml. Leishmania infantum parasites were found both in colon biopsy samples and in peripheral blood. Moreover, liver biopsy showed large macrophages containing Leishmania infantum. An additional course of 1-Ampho-B resulted in clinical recovery and was followed by maintenance therapy. The eGFR was normal. Compliance with CART was poor and the CD4 T-cell count remained below 200 cells $/ \mathrm{mm}^{3}$.

In 2006 the patient presented with nephrotic syndrome. $\mathrm{C} 4$ and $\mathrm{C} 3$ concentrations were normal, while HIV viral load and CD4 T-cell count were 41,000 copies/ml and 12 cells $/ \mathrm{mm}^{3}$, respectively. Leishmania amastigotes were observed on a blood smear. A renewed course of l-ampho-B resulted in remission of the nephrotic syndrome.

In 2007, the patient was admitted again with odema, a weight gain of $4 \mathrm{kgs}$ and dyspnoea. He presented this time with nephritic syndrome and acute kidney injury. Complement activity was normal. Gastroscopy and colonoscopy revealed several parasites in the stomach, duodenum and colon. Qualitative Leishmania infantum PCR on blood and gut samples was positive. Histological examination of kidney tissue showed type III MPGN with free Leishmania parasites in a capillary lumen (Figure 1A,B,C,D). Moreover, Leishmania infantum PCR was positive on the biopsy sample. 
Table 1 Description of cases of VL with renal injury and outcome

\begin{tabular}{|c|c|c|c|c|}
\hline & Case 1 & Case 2 & Case 3 & Case 4 \\
\hline \multicolumn{5}{|l|}{ Clinical characteristics } \\
\hline Age & 40 & 35 & 24 & 49 \\
\hline Years since HIV contamination & 15 & 11 & 24 & 16 \\
\hline Years since diagnosis of visceral Leishmaniosis & 11 & 9 & 2 & 19 \\
\hline Renal syndrome & $\begin{array}{l}\text { Nephritic } \\
\text { syndrome }\end{array}$ & Nephrotic syndrome & AKI & Nephrotic syndrome \\
\hline \multicolumn{5}{|l|}{ Biology } \\
\hline Leishmania quantitative PCR test (parasites/ml) & 6225 (blood) & 1700000 (kidney) & Not available & 11570 (blood) \\
\hline C4 concentration (normal range $0.14-0.33 \mathrm{~g} / \mathrm{l}$ ) & 0.12 & Not available & 0.14 & 0.2 \\
\hline Cryoglobulin & Positive & Not available & Positive & Positive type 2 \\
\hline HCV serology & Negative & Negative & Negative & Positive \\
\hline HCV viral load in blood (qualitative) & - & - & - & Negative \\
\hline $\begin{array}{l}\text { Serum albumin }(g / l) \text { at time of diagnosis or } \\
\text { during follow-up }\end{array}$ & 25 & $22 / 14$ & - & $20 / 24$ \\
\hline Plasma hyper-gammaglobulinemia & Yes & Unknown & Yes & Yes \\
\hline Platelets $>150000$ giga/L at time of renal biopsy & Yes & Yes & Yes & Yes \\
\hline Severe clottingdysfunction & No & No & No & No \\
\hline Hepatic function & Normal & Normal & Normal & Normal \\
\hline HIV viral load (copies/ml) & 162 & 41000 & 2000 & $<40$ \\
\hline CD4 T-cell count (cells $/ \mathrm{mm}^{3}$ ) & 114 & 12 & 70 & 84 \\
\hline CD4 T-cell nadir (cells $/ \mathrm{mm}^{3}$ ) & 46 & 12 & 50 & 84 \\
\hline $\begin{array}{l}\text { Plasma creatinine concentrations (year, }[\mu \mathrm{mol} / \mathrm{l}] \text { ) } \\
\text { diagnosis/follow-up }\end{array}$ & $143 / 152$ & $\begin{array}{l}2006(100) / 2007(265) / \\
2008(488)\end{array}$ & $154 / 99$ & $55 / 60$ \\
\hline CKD-EPI $\left(\mathrm{ml} / \mathrm{min} / 1.73 \mathrm{~m}^{2}\right)$ diagnosis/follow-up & $48 / 47$ & $105 / 90 / 52$ & & 69 \\
\hline \multicolumn{5}{|l|}{ Urinalysis } \\
\hline Daily proteinuria (g/day) Diagnosis/follow-up & 2.1 & $1.5 / 2.0 / 3.0$ & $0.3 / 0.5$ & $2.0 / 0.5$ \\
\hline Hematuria/Leukocyturia & $+/-$ & $+/-$ & $-/+$ & $-/-$ \\
\hline Kidney histological findings & MPGN III & $\begin{array}{l}\text { MPGN III and Interstitial } \\
\text { nephropathy }\end{array}$ & $\begin{array}{l}\text { Interstitial } \\
\text { nephropathy }\end{array}$ & $\begin{array}{l}\text { MPGN III and interstitial } \\
\text { nephropathy }\end{array}$ \\
\hline \multicolumn{5}{|l|}{ Treatment and outcome } \\
\hline \multirow[t]{2}{*}{ VL treatment regimen } & $\begin{array}{l}\text { I-Amph-B, } \\
\text { Pentamidine }\end{array}$ & I-Amph-B, Pentamidine, & I-Amph-B & I-Amph-B, Miltéfosime \\
\hline & & Miltefosine & & \\
\hline Renal outcome & Improved & Not improved & Improved & $\begin{array}{l}\text { Improved but worsened } \\
\text { at clinical relapse }\end{array}$ \\
\hline Patient outcome & Partial recovery & Died & Partial recovery & Died \\
\hline
\end{tabular}

VL: Visceral Leishmaniasis.

PCR: Polymerase Chain Reaction.

CKD-EPI: Chronic Kidney Disease Epidemiology Collaboration Equation.

I-Amph-B: liposomal Amphotericine B.

Compliance with antiretroviral treatment remained poor and in 2008 the patient was admitted to hospital for the fourth time due to renewed relapse with diarrhœa, weight loss and odema. His HIV-RNA and CD4 T-cell count were 74,000 copies $/ \mathrm{ml}$ and 200 cells $/ \mathrm{mm}^{3}$, respectively. The patient died due to renal failure despite anti-parasitic treatment with l-Ampho-B.

\section{Case report $\mathrm{n}^{\circ} 3$}

A 24 year-old female patient, born in Italy and a resident of the Sanremo area (Liguria, North-Western Italy), HIV-infected via maternal-foetal transmission, was admitted to hospital in 2012 for weight loss and AKI.

At the time of admission, her cART regimen consisted in etravine, raltegravir and boosted darunavir. The CD4 
Table 2 Description of kidney histo-pathological diagnosis

\begin{tabular}{|c|c|c|c|c|}
\hline Patient & Case 1 & Case 2 & Case 3 & Case 4 \\
\hline Renal histology & MPGN type III & MPGN type III & Acute interstitial nephritis & MPGN type III \\
\hline \multirow[t]{3}{*}{ Light microscopy } & \multirow[t]{3}{*}{$\begin{array}{l}\text { Diffuse } \\
\text { hypercellularity and } \\
\text { thickening of } \\
\text { glomerular basement } \\
\text { membrane. }\end{array}$} & $\begin{array}{l}\text { Subendothelial and } \\
\text { subepithelial deposits with } \\
\text { mesangial interposition } \\
\text { associated with basement } \\
\text { membrane spikes }\end{array}$ & $\begin{array}{l}\text { Acute interstitial nephritis: edema } \\
\text { associated with interstitial } \\
\text { lymphoplasmocytic infiltration in } \\
\text { addition to mild tubulointerstitial } \\
\text { fibrosis. }\end{array}$ & $\begin{array}{l}\text { Subendothelial and } \\
\text { subepithelial deposits and } \\
\text { mesangial interposition } \\
\text { associated with basement } \\
\text { membrane spikes. }\end{array}$ \\
\hline & & $\begin{array}{l}\text { Free Leishmania in a capillary } \\
\text { lumen }\end{array}$ & $\begin{array}{l}\text { Tubules are invaded by } \\
\text { lymphocytes and areas of } \\
\text { necrosis are visualized. }\end{array}$ & $\begin{array}{l}\text { Interstitial granuloma. Positive } \\
\text { PCR for Leishmania infantum } \\
\text { in urine and in renal biopsy }\end{array}$ \\
\hline & & $\begin{array}{l}\text { Positive PCR for Leishmania } \\
\text { infantum in the renal biopsy }\end{array}$ & $\begin{array}{l}\text { Glomeruli are uninvolved. Free } \\
\text { Leishmania in a capillary lumen }\end{array}$ & \\
\hline Immunofluorescence & $\begin{array}{l}\text { Mesangial and } \\
\text { endomembranous } \\
\text { deposits of lgG, IgM, } \\
\text { C3 and } \mathrm{Clq}\end{array}$ & $\begin{array}{l}\text { Fine granular deposition of lgG } \\
\text { and } \mathrm{C} 3 \text { in the mesangium and } \\
\text { along the peripheral capillary loops }\end{array}$ & $\begin{array}{l}\text { Deposits of } \lg G \text { and } \lg M \text { with a } \\
\text { mesangial pattern }\end{array}$ & $\begin{array}{l}\text { Mesangial and } \\
\text { endomembranous deposits } \\
\text { of } \lg G \text { and } C 3\end{array}$ \\
\hline
\end{tabular}

MPGN: Membrano-proliferative glomeruolonephritis.

PCR: Polymerase Chain Reaction.

T-cell count was low $\left(70\right.$ cells $\left./ \mathrm{mm}^{3}\right)$ and plasma HIVRNA numbered2,000 copies $/ \mathrm{ml}$. Previous personal medical history included pneumocystis pneumonia, œsophageal candidiasis, cytomegalovirus retinitis and, more recently, two episodes of VL over the last two years. Both episodes were treated with l-Ampho-B followed by secondary prophylaxis. Several antiretroviral regimens had been administered, but compliance had never been satisfactory, viral load had been undetectable during only a few months and the CD4 T-cell count had consistently remained below 200 cells $/ \mathrm{mm}^{3}$, with a nadir of 50 cells/ $\mathrm{mm}^{3}$. Gastric and lymph node biopsy revealed Leishmania infantum, and a renal needle biopsy was performed to investigate AKI associated with proteinuria. Light microscopy examination showed interstitial nephritis with free Leishmania in interstitial tissue while no involvement of the glomeruli was observed. Immunofluorescence microscopy revealed a mesangial pattern of IgG and IgM deposits (Figure 2A,B)

Treatment with 1-Ampho-B was started and resulted in improved eGFR. Antiretroviral treatment was modified according to genotyping results. The patient was

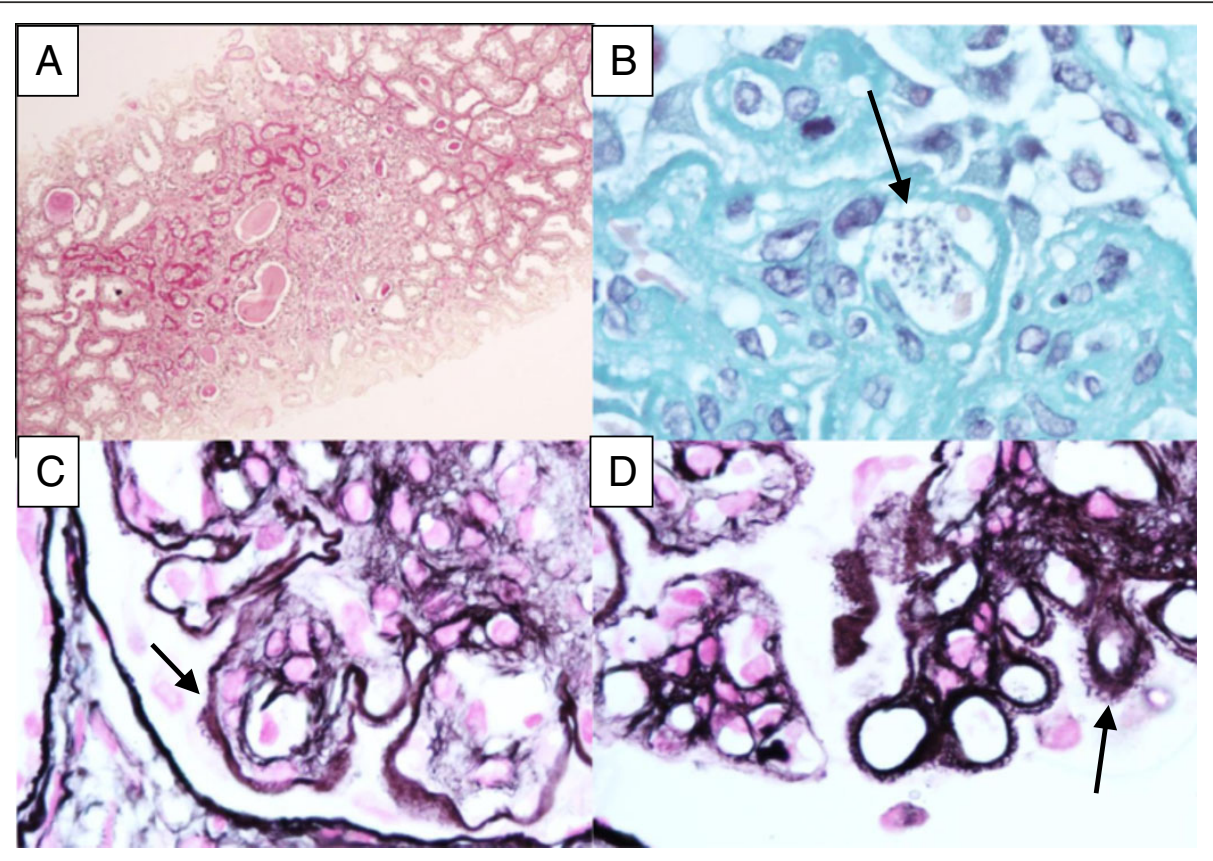

Figure 1 Main histological findings in patient 2, who had type III membrano-proliferative glomerulonephritis (MPGN). A. Cortical kidney inflammation (PAS x1000). B. Clusters of circulating Leishmania free parasytes in capillary (arrow) (Trichrome stain x1000). C. Prominent double contour formations (arrow) (Silver stain x1000). D. Basement membrane spikes (Silver stain x1000). 


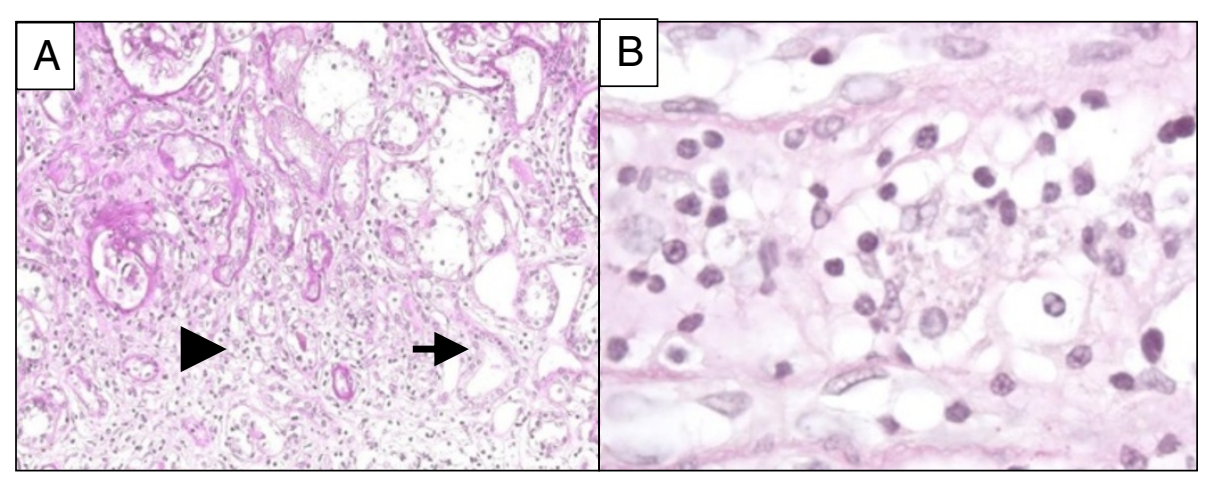

Figure 2 Main histological results in patient 3, who presented acute interstitial nephritis without glomerular involvement. A. Acute interstitial nephritis: oedema associated with an infiltration of interstitial lymphoplasmacytoid cells (Arrowhead). Tubules are invaded by lymphocytes (Arrow). Glomeruli are uninvolved. (PAS x200). B. Free Leishmania in interstitial tissue (PAS ×1000).

discharged and secondary prophylaxis with l-Ampho-B was continued. A recent outpatient follow-up visit showed stable renal function, normal urinary sediment microscopy and proteinuria of $0.53 \mathrm{~g} / 24 \mathrm{hrs}$. Despite the persistent clinical relapse-free period, PCR remained positive on blood (736 parasites/ml) with a CD4 T-cell count below 200 cells $/ \mathrm{mm}^{3}$ while the HIV viral load did not exceed50 copies $/ \mathrm{ml}$.

\section{Case report $n^{\circ} 4$}

A 49-year-old male patient, born and residing in the Nice area (Alpes-Maritimes, South-Eastern France), HIV and hepatitis $\mathrm{C}(\mathrm{HCV})$ co-infected since the age of 16, was admitted to hospital in 2011 for weight loss, œedema and nephrotic syndrome without hematuria. The eGFR was normal. VL had been previously diagnosed in 1991 and treated, resulting in symptom resolution.

Laboratory tests upon admission showed undetectable HCV and HIV viral loads, and a CD4 T-cell count of 84 cells $/ \mathrm{mm}^{3}$. The antiretroviral regimen included abacavir, lamivudine and lopinavir/ritonavir.

Antiparasitic treatment with miltefosine was initiated, resulting in clinical and biological improvement.
Leishmania infantum PCR on blood was negative, but was positive on urine. Kidney histological findings showed type III MPGN and interstitial granuloma. with positive Leishmania infantum PCR on kidney tissue (Figure 3A,B). Although $\mathrm{HCV}$ co-infection may also cause renal injury, the undetectable $\mathrm{HCV}$ viral load and positive Leishmania infantum PCR suggested that MPGN was more likely to be linked to VL than to $\mathrm{HCV}$. One year later, the patient was re-admitted due to clinical relapse of VL. HIV-RNA on admission was 1,700 copies/ml and CD4 T-cells numbered $78 / \mathrm{mm}^{3}$. Leishmania infantum PCR on blood was positive $(11,570$ parasites/ml). In spite of treatment with 1Ampho-B, the patient died a few days after admission due to severe intestinal bleeding.

\section{Discussion}

We describe four cases of VL due to Leishmania infantum in HIV-infected patients in the cART era, with specific PCR or microscopic proof of renal involvement.

All patients had severe immunosuppression, and had presented with recurring episodes of clinical relapse of VL over a follow-up period of several years. Moreover,

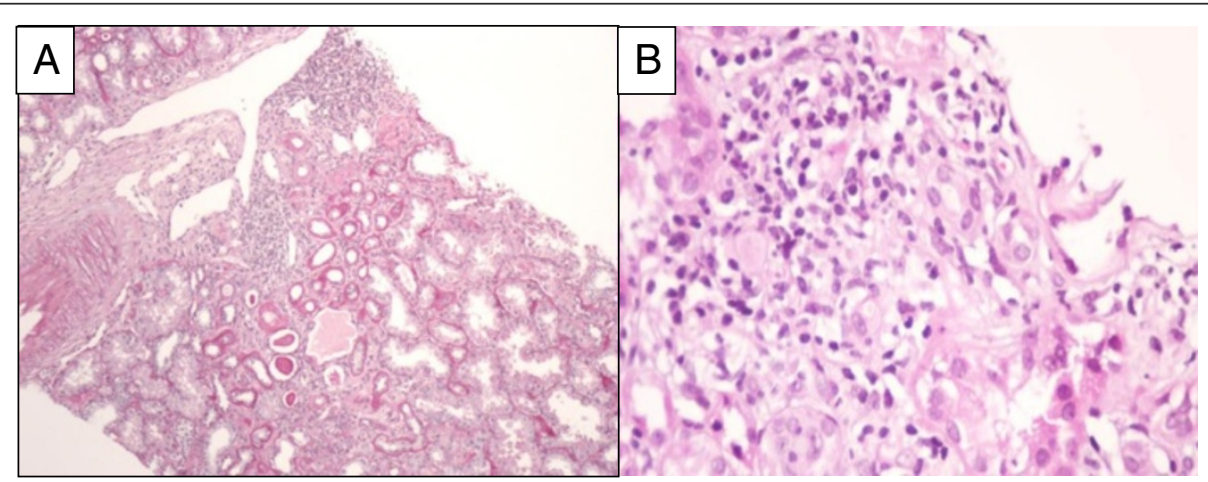

Figure 3 Description of renal biopsy results for patient 4, who presented type III MPGN. A. Inflammation within the cortical kidney (PAS x100). B. Giant cell granuloma. (HE stain x 400). 
they had partial or complete recovery of renal function after anti-parasitic treatment associated with better control of HIV infection. The main clinical presentations included nephrotic or nephritic syndrome secondary to type III MPGN or acute kidney injury secondary to interstitial nephritis.

According to the WHO classification, based on ultrastructural alterations in the glomerular basement membrane, MPGN is subdivided into 3 categories: type I (sub-endothelial deposits), type II (intra-membranous dense deposits) and type III, where deposits are found in the sub-endothelial and mesangial region, similarly to type I, but, in addition, with numerous sub-epithelial deposits [24]. Histological findings reported in our series are in line with sporadic cases described in humans and in studies on dogs, where type III MPGN was the most commonpattern [15-22,25,26]. Interestingly, free Leishmania were observed inside the capillary lumen of two patients.

MPGN during VL is probably the result of immune complex deposition occurring during chronic infection $[15,24,27]$. However, other mechanisms of injury have been suggested in dogs: indeed, there is growing evidence that T-cell migration into the glomeruli and adhesion molecules play a fundamental role in the pathogenesis of certain immunologically-mediated cases of glomerulonephritis [27]. Costa et al. [27] found considerably higher numbers of CD4 T-cells in dogs with VL compared to uninfected animals, with no relevant associated immune complex deposition. The number of T-cells was correlated to the quantity of Leishmania antigen in phagocytic cells, suggesting that the parasite itself could directly drive the inflammatory infiltrate in the glomeruli. Enhanced expression of adhesion molecules, such as P-selectin and ICAM-1, has also been found in the mesangium and glomerular capillaries of animals and humans with $\mathrm{VL}$, thus suggesting that newly migrated platelets could play a role in the pathogenesis of renal injury. Finally, diminished apoptosis may be another possible mechanism contributing to the persistence and progression of glomerular hyper-cellularity [27].

Acute interstitial nephritis was the other presentation of renal involvement secondary to Leishmania infantum infection reported in this series. This is probably the result of parasitic dissemination, as reported by other authors in a human kidney transplant recipient [19] and in dogs $[25,26]$. Tubular necrosis could be secondary to ischemia due to small vessel obliteration by Leishmania spp., while haemolysis and necrotizing tubulitis could be a consequence of parasitic invasion and inflammatory response [28,29].

The correlation between immunosuppression and clinical relapse of VL has been suggested by Bourgeois et al., who showed that the persistence of CD4 T-cell counts $<100$ cells $/ \mathrm{mm}^{3}$ is one of the main risk factors for relapse [30]. Since the advent of cART, features of HIV/Leishmania spp. coinfection include a chronic course of parasitic disease with latent parasitemia and a high rate of relapse. Bourgeois et al. [14] defined the condition as "active chronic VL", where patients have long-term persistence of circulating Leishmania species with alternating symptomatic and asymptomatic phases. As showed by Kubar et al. [31], patients with relapsing VL generally have lower CD4 T-cell counts than HIVinfected patients with primary $\mathrm{VL}$, suggesting that in addition to the T-cell-mediated response, essential at the time of primary Leishmania infection, supplementary mechanisms might operate in case of chronic infection.

Patients described in this series received various antiparasitic agents including l-Ampho-B, pentamidine and miltefosine. They all responded, at least partially, but they sufferedseveral relapses despite secondary prophylaxis. Data regarding secondary prophylaxis of VL in HIV-infected patients are scarce, explaining the absence of guidelines favouring a particular regimen [32]. There is no consensus on the management of active chronic VL. It is currently suggested that parasite detection by PCR, together with CD4 T-cell count, may guide decisions for prolonging or stopping prophylaxis in HIVinfected patients [33-36]. Bourgeois et al. suggest that secondary prophylaxis could be discontinued in patients taking cART when either 1) PCR remains negative for at least 6 months and CD4 T-cell count is $>200$ cells $/ \mathrm{mm}^{3}$ or 2) CD4 T-cell count is $<200$ cells $/ \mathrm{mm}^{3}$ but PCR remains negative for at least 18 months [30].

This case series showed that the clinical outcome of VL and renal injury is associated with viro-immunological control of HIV infection, suggesting that immune restoration plays a pivotal role in preventing relapse. In this case series, suboptimal compliance with antiretroviral treatment was probably the main cause of poor immune recovery, as proven by frequent episodes of viral replication during follow-up. However, VL itself might play a role: Leishmania co-infection could enhance viral replication and immune activation, thus contributing to CD4 T-cell depletion and increasing the risk of reactivation of latent infections $[37,38]$. Thus, even patients with successful antiretroviral treatment could be at risk for Leishmania reactivation.

Finally, in this series, patients presented with active chronic VL progressing over a protracted course, ranging from 2 to 19 years (median 8 yrs). In mixed cryoglobulinemia due to hepatitis $C$ virus, another condition mediated by immune complex deposition, vasculitisrelated symptoms, including renal involvement, are associated with longer duration of HCV infection [39]. Similarly, in active chronic VL, prolonged infection may be required to develop renal disease. 


\section{Conclusions}

Our results suggest that the main histological findings in case of renal involvement due to Leishmania infantum infection in HIV-infected patients are type III MPGN and acute interstitial nephritis, with specific histological features similar to those observed in canine leishmaniasis. Poor immune status in HIV-infected patients, altering the capacity for parasite clearance, and prolonged course of chronic active VL in this population may lead to the development of these specific renal lesions. These patients should thus be regularly screened for Leishmania infantum infection and their renal function closely monitored.

\section{Consent}

Written informed consent was obtained from patients for publication of this Case report and any accompanying images. A copy of the written consent is available for review by the Editor of this journal.

\section{Competing interests}

The authors declare that they have no competing interests.

\section{Authors' contributions}

Conceived and designed the study: MV, OM, PYJ, CP, PM, ER. Data collection: $M V, O M, D A, G G, A B, N M, E C, C D, I D, B V, G F, C P, L S, R K$. Wrote manuscript: MV, OM. Edited the manuscript: MV, OM, CP, PM, ER. All authors read and approved the final manuscript.

\section{Acknowledgments}

We thank all patients for accepting to participate in the collection of data We also wish to thank Julie Medway for paper revision.

\section{Author details}

${ }^{1}$ Department of Internal Medicine, Cannes General Hospital, Cannes, France. 2Department of Nephrology, Dialysis and Transplantation, Nice University Hospital, Nice, France. ${ }^{3}$ Department of Public Health, Nice University Hospital, Nice, France. ${ }^{4}$ Laboratory of Human Motricity, Education and Health (LAMHESS), University of Nice Sophia-Antipolis, Nice, France. ${ }^{5}$ Department of Histopathology, Nice University Hospital, Nice, France. ${ }^{6}$ Department of Internal Medicine, Nice University Hospital, Nice, France. ${ }^{7}$ Parasitology and Mycology, Nice University Hospital and Inserm U 1065, Nice-Sophia Antipolis University, Equipe 6, Centre Méditerranéen de Médicine Moléculaire, Nice, France. ${ }^{8}$ Department of Infectious Diseases, Sanremo General Hospital, Sanremo, Italy. 'Department of Histopathology, Genoa University Hospital, Genoa, Italy. ${ }^{10}$ Department of Nephrology, Cannes General Hospital, Cannes, France.

Received: 31 March 2014 Accepted: 14 October 2014

Published online: 30 October 2014

\section{References}

1. Berman JD: Human leishmaniasis: clinical, diagnostic and chemotherapeutic developments in the last 10 years. Clin Infect Dis 1997, 24(Suppl 4):684-703.

2. Alvar J, Cañavate C, Gutiérrez-Solar B, Jiménez M, Laguna F, López-Vélez R, Molina R, Moreno J: Leishmania and human immunodeficiency virus co-infection: the first 10 years. J Clin Microbiol Rev 1997, 10:298-319.

3. Oliveira CMC, Oliveira MLMB, Andrade SCA, Girao CS, Ponte CN, Mota MU, Fernandes PFCBC, Campos HH, Esmeraldo RM, Evangelista JB Jr: Visceral leishmaniasis in renal transplant recipients: clinical aspects, diagnostic problems, and response to treatment. Transplant Proc 2008, 40(Suppl 3):755-760

4. Alvar J, Velez ID, Bern C, Herrero M, Desjeux P, Cano J, Jannin J, Den Boer M, WHO Leishmaniasis Control Team: Leishmaniasis worldwide and global estimates of its incidence. Plos One 2012, 7(suppl. 5):e35671.
5. Pérez-Molina JA, López V, Guerrero A: Secondary prophylaxis for visceral leishmaniasis in HIV-infected individuals. Am J Med 1997, 102(Suppl 1):132. 6. Herwaldt BL: Leishmaniasis. Lancet 1999, 354:1191-1199.

7. Alvar J, Aparicio P, Aseffa A, Den Boer M, Cañavate C, Dedet JP, Gradoni L, Ter Horst R, López-Vélez R, Moreno J: The relationship between leishmaniasis and AIDS: the second 10 years. Clin Microbiol Rev 2008, 21(Suppl 2):334-359.

8. Rosenthal E, Marty P, Poizot M, Reynes J, Platlong F, Lafeuillade A, Jaubert D, Boulat O, Dereure G, Gamabarelli A: Visceral leishmaniasis and HIV-1 co-infection in Southern France. Trans R Soc Trop Med Hyg 1995, 89:159-162.

9. Rosenthal E, Tempesta S, Del Giudice P, Marty P, Desjeux P, Pradier C, Le Fichoux Y, Cassuto JP: Declining incidence of visceral leishmaniasis in HIV-infected individuals in the era of highly active antiretroviral therapy. AIDS 2001, 15:1884-1885.

10. Rybniker J, Goede V, Mertens J, Ortmann M, Kulas W, Kochanek M, Benzing $T$, Arribas JR, Fatkenheuer G: Treatment of visceral leishmaniasis with intravenous pentamidine and oral fluconazole in an HIV-positive patient with chronic renal failure-a case report and brief review of the literature. Int J Infect Dis 2010, 14:522-525.

11. Dujardin JC, Campino L, Cañavate C, Dedet JP, Gradoni L, Soteriadou K, Mazeris A, Ozbel Y, Boelaert M: Spread of vector-borne diseases and neglect of Leishmaniasis. Europe Emerg Infect Dis 2008, 14(Suppl 7):1013-1018.

12. Rosenthal E, Marty P: Leishmaniose viscérale. Rev Prat 2004, 54(Suppl 20):2211-2216.

13. Del Giudice P, Mary-Krause M, Pradier C, Grabar S, Dellamonica P, Marty P, Gastaut JA, Costagliola D, Rosenthal E, French Hospital Database on HIV Clinical Epidemiologic Group: Impact of highly active antiretroviral therapy on the incidence of visceral leishmaniasis in a french cohort of patients infected with human immunodeficiency virus. J Infect Dis 2002, 186:1366-1370.

14. Bourgeois N, Bastien P, Reynes J, Makinson A, Rounet I, Lachaud L: Active chronic visceral leishmaniasis" in HIV-infected patients demonstrated by biological and clinical long-term follow-up of 10 patients. HIV Med 2010, 11(Suppl 10):670-673.

15. Amann K, Bogdan C, Harrer T, Rech J: Renal leishmaniasis as unusual cause of nephrotic syndrome in an HIV patient. J Am Soc Nephro/ 2012, 23:586-590

16. Davidson RN: Practical guide for the treatment of leishmaniasis. Drugs 1998, 56:1009-1018.

17. Suankrantay C, Suwanpimolkul G, Wilde H, Siriyasatien P: Case report: Autochtonus visceral leishmaniasis in a human immunodeficiency virus (HIV)-infected patient: the first in Thailand and review of the literature. Am J Trop Med Hyg 2010, 82(Suppl 1):4-8.

18. Jarvis JN, Lockwood DN: Clinical aspects of visceral leishmaniasis in HIV infection. Curr Opin Infect Dis 2013, 26:1-9.

19. Dettwiler S, McKee T, Hadaya K, Chappuis F, van Deiden C, Moll S: Visceral Leishmaniasis in a kidney transplant recipient: parasitic interstitial nephritis, a cause of renal dysfunction. Am J Transplant 2010, 10:1486-1489.

20. Alex S, Criado C, Fernandez-Guerrero ML, de Gorgolas M, Petkov V, Garcia Perez A, Egido J, Barat A, Manzarbeitia F, Carmelo C, Ortiz A: Nephrotic syndrome complicating chronic visceral leishmaniasis: re-emergence in patients with AIDS. Clin Nephrol 2008, 70(Suppl 1):65-68.

21. Clevenbergh P, Nkoumou Okome M, Benoit S, Bendini JC, De Salvador F, Elbeze M, Cassuto E, Marty P, Dellamonica P: Acute renal failure as initial presentation of visceral leishmaniasis in an HIV-1 infected patient. Scand J Infect Dis 2002, 34(Suppl 7):546-547.

22. Daher EF, Rocha NA, Oliveira MJ, Franco LF, Oliveira JL, Silva Junior GB, Abreu KL, Henn GA, Martins AM, Libório AB: Renal function improvement with pentavalent antimonial agents in patients with visceral leishmaniasis. Am J Nephrol 2011, 33(Suppl 4):332-336.

23. Mary C, Faraut F, Lascombe L, Dumon H: Quantification of Leishmania infantum DNA by a real-time PCR assay with sensitivity. J Clin Microbiol 2004, 42:5249-5255.

24. Aresu L, Valenza F, Ferroglio E, Pregel P, Uslenghi F, Tarducci A, Zanatta R: Membranoproliferative glomerulonephritis type III in a simultaneous infection of Leishmania infantum and Dirofilaria immitis in a dog. J Vet Diagn Invest 2007, 19(Suppl 5):569-572.

25. Rollino C, Bellis D, Beltrame G, Basolo B, Montemagno A, Bucolo S, Ferro M, Quattrocchio G, Coverlizza S, Quarello F: Acute renal failure in leishmaniasis. Nephrol Dial Transplant 2003, 18:1950-1951. 
26. Poli A, Abramo F, Mancianti F, Nigro M, Pieri S, Bionda A: Renal involvement in canine leishmaniasis: a light-microscopic, immunohistochemical and electron-microscopic study. Nephron 1991, 57:444-452.

27. Costa FAL, Prianti MG, Silva TC, Silva SMMS, Guerra JL, Goto H: T cells, adhesion molecules and modulation of apoptosis in visceral leishmaniasis glomerulonephritis. BMC Infect Dis 2010, 10:112.

28. Clerici M, Hakim FTD, Venzon DJ, Blatt S, Hendrix CW, Wynn TA, Shearer GM: Changes in interleukine 2 and interleukine 4 in asymptomatic human immunodeficiency virus seropositive individuals. J Clin Invest 1993, 91:759-765.

29. D'Ettorre G, Ceccarelli G, Carnevalini M, Forcina G, Zaffiri L, Massetti AP Mastroianni CM, Vullo V: Central role of interleukin-15 in human immunodeficiency virus (HIV)-infected patients with visceral leishmaniasis. Acta Trop 2006, 99:83-87.

30. Bourgeois N, Lachaud L, Reynes J, Rouanet I, Mahamat A, Bastien P: Long-term monitoring of visceral leishmaniasis in patients who have AIDS. J Acquir Immune Defic Syndr 2008, 48(Suppl 1):13-19.

31. Kubar J, Marty P, Lelièvre A, Quaranta JF, Staccini P, Caroli-Bosc C, Le Fichoux $Y$ : Visceral leishmaniasis in HIV-positive patients: primary infection, reactivation and latent infection. Impact of the CD4+ T-lymphocytes counts. AIDS 1998, 12:2147-2153.

32. Buffet PA, Rosenthal E, Gangneux JP, Lightburne E, Couppié P, Morizot G, Lachaud L, Marty P, Dedet JP, Societé de Pathologie Exotique: Therapy of leishmaniasis in France: consensus on proposed guidelines. Presse Med 2011, 40(Suppl. 2):173-184.

33. Pintado $V$, Lopez-Velez L: Visceral leishmaniasis associated with human immunodeficiency virus infection. Enferm Infecc Microbiol Clin 2001 19:353-357.

34. Cota GF, de Sousa MR, Demarqui FN, Rabello A: The diagnostic accuracy of serologic and molecular methods for detecting visceral leishmaniasis in HIV infected patients: meta-analysis. PLoS Negl Trop Dis 2012, 6(5):e1665.

35. Mary C, Faraut F, Drogoul MP, Xeridat B, Schleinitz N, Cuisenier B, Dumon H: Reference values for Leishmania infantum parasitemia in different clinical presentations: quantitative polymerase chain reaction for therapeutic monitoring and patient follow-up. Am J Trop Med Hyg 2006, 75(Suppl 5):858-863.

36. Bossolasco S, Gaiera G, Olchini D, Gulletta M, Martello L, Bestetti A, Bossi L, Germagnoli L, Lazzarin A, Uberti-Foppa C, Cinque P: Real-time assay for clinical management of human immunodeficiency virus-infected patients with visceral leishmaniasis. J Clin Microbiol 2003, 41:5080-5084

37. Okwor I, Uzonna JE: The immunology of Leishmania/HIV coinfection. Immunol Res 2013, 56:163-171.

38. Andreani G, Lodge R, Richard D, Tremblay MG: Mechanisms of interaction between protozoan parasites and HIV. Curr Opin HIV AIDS 2012, 7:276-282.

39. Sene D, Ghillani-Dalbin P, Thibault V, Guis L, Musset L, Duhaut P, Poynard T, Piette JC, Cacoub P: Longterm course of mixed cryoglobulinemia in patients infected with hepatitis C virus. J Rheumatol 2004, 31:2199-2206.

doi:10.1186/s12879-014-0561-9

Cite this article as: Vassallo et al:: Visceral leishmaniasis due to

Leishmania infantum with renal involvement in HIV-infected patients. BMC Infectious Diseases 2014 14:561.

\section{Submit your next manuscript to BioMed Central and take full advantage of:}

- Convenient online submission

- Thorough peer review

- No space constraints or color figure charges

- Immediate publication on acceptance

- Inclusion in PubMed, CAS, Scopus and Google Scholar

- Research which is freely available for redistribution 